\title{
Genetic Variability and Interrelationships among Quantitative Traits in Rapeseed (Brassica napus 1.) Advanced Lines
}

\author{
V. Rameeh \\ Received: $23^{\text {rd }}$ March 2015 / Accepted : $16^{\text {th }}$ July 2015
}

\begin{abstract}
Improvement of the new rapeseed (Brassica napus L.) cultivars requires efficient tools to monitor traits relationship in a breeding program. Thirty six rapeseed genotypes were evaluated based on randomized complete block design with three replications at Baykola Agricultural Research Station during 2010-11 and 2011-12 growing seasons. Significant genotypes effects were exhibited for phenological traits, plant height, yield components, seed and oil yields, indicating significant genetic differences among the genotypes. Broad sense heritability values were greater for days to flowering (0.98), pods per plant (0.71) and seeds per pod (0.77), indicating that these traits are controlled mainly by genetic effects and therefore selection of these traits may be effective for improving seed yield. Pods per plant and seeds per pod were significant positive correlated with seed yield and the results of stepwise regression analysis indicated that these traits explained $73 \%$ of total yield variation. On the basis of cluster analysis, all the genotypes were classified in three groups, and the group with high mean values of plant height, pods per plant and seeds per pod had also high mean values of seed and oil yields.
\end{abstract}

Keywords: coefficient of variation, cluster analysis, stepwise regression, rapeseed.

\section{INTRODUCTION}

Rapeseed is an important species from Brassica genus with high quality source of vegetable oil for the food industry and supplies protein to the animal feed market (Khachatourians et al., 2001; Mahasi and Kamundia, 2007). It is an important crop in Iran for more than a decade and has major role in providing self-sufficiency in edible oil to the country. Hence, it is necessary to develop new varieties of rapeseed with high seed yield. To increase the yield, study of direct and indirect effects of yield components provides the basis for its successful breeding program, and hence, the problem of yield increase can be more effectively tackled on the basis of performance of yield components, and selection for closely related characters (Friedt et al., 2007; Aytac et al., 2008; Marjanovic-Jeromela et al., 2009). The multivariate analysis, particularly factor and cluster analyses, are utilized for evaluation of germplasm for various traits in a large number of accessions. Cluster analysis assigns genotypes into qualitative homogenous groups based on response similarities, and also assists to classify genotypes. The method among group means produces a dendrogram showing successive fusion of individuals. Greater heterotic effect is generated when clusters are divergent. Genetic diversity among the Brassica genotypes was assessed by Choudhary and Joshi (2001) using cluster analysis. The morphological characters viz., days to flowering, plant height, secondary branches per plant, and 1000-seed weight contributed maximum towards genetic divergence (Leilah and Al-Khatee 2005; Aytac and Kinaci 2009; Naderi and Emam 2010). Determination of correlation coefficients is an important statistical procedure to evaluate 
breeding programs for high yield, as well as to examine direct and indirect contributions to yield variables (Khan et al., 2006; Ivanovska et al., 2007; Basalma, 2008; Hashemi et al., 2010; Semahegn Belete, 2011). Zang and Zhou (2006) reported that pods per plant, seeds per plant, and 1000-seed weight traits were positively correlated with seed yield. On the other hand, Length of pod was negatively correlated with seed yield. Jeromela et al. (2007) studied 30 rapeseed varieties and demonstrated that pods per plant have the highest correlation with seed yield. Khan et al. (2008) also reported the positive significance correlation between seed yield and plant height, pods per plant, seeds per pod, and pod length. Sheikh et al. (1999) found high heritability estimates coupled with high genetic advanced for seed yield per plant, pods per plant and seed weight in rapeseed (Brassica campestris) genotypes. They also reported positive correlation of all the yield components with seed yield. Genetic variability is prerequisite for improving any crop plant.

The objectives of the present study were to estimate the genetic coefficient of variation, broad sense heritability, relationship among yield associated traits for improving seed yield in spring type of rapeseed advanced lines and cultivars, and also classify the genotypes via factor and cluster analyses.

\section{MATERIALS AND METHODS}

The material under study consisted of 36 rapeseed (B. napus L.) genotypes including four checks and 32 advanced lines which were selected based on different agronomic characters (Table 01). The genotypes were evaluated based on randomized complete block design with three replications at Baykola Agriculture Research Station, located in Neka, Iran $\left(53^{\circ}, 13^{\prime} \mathrm{E}\right.$ longitude and $36^{\circ} 43^{\prime} \mathrm{N}$ latitude,
$15 \mathrm{~m}$ above sea level) during 2010-11 and 201112 growing seasons. The plots consisted of four rows $5 \mathrm{~m}$ long and $30 \mathrm{~cm}$ apart. The distance between plants on each row was $5 \mathrm{~cm}$ resulting in approximately 400 plants per plot, which were sufficient for statistical analysis. Crop management practices like land preparation, crop rotation, fertilizer, and weed control were followed as recommended for local area. All the plant protection measures were adopted to make the crop free from insects. Phenological traits including days to flowering, and days to maturity were determined based on phenological stages of the genotypes in each plot. Plant height and pods per plant were recorded based on 10 randomly selected plants of each plot. Seed yield (adjusted to $\mathrm{kg} / \mathrm{ha}$ ) was recorded based on two middle rows of each plot. Oil content was estimated with the help of nuclear magnetic resonance spectrometry (Madson, 1976). Oil yield was calculated by multiply oil percentage and seed yield for each genotype.

Total genetic, phenotypic, environmental variances and broad-sense heritability were calculated following Singh et al.,1993. Variance components were estimated using expectations as below:

$\mathrm{EV}=\mathrm{MSE}, \quad \mathrm{GV}=(\mathrm{MSG}-\mathrm{MSYG}) /(\mathrm{r} . \mathrm{y})$ ,$P V=(E V+G V)$ where $r, y, E V, G V$ and PV are number of replications and years, variance components for error, genotype and phenotype, respectively, and MSE and MSG are the observed values of the mean squares for error and genotype, respectively. Broad sense heritability estimates were calculated on entry basis using the following relationship: hi ${ }^{2}=$ GV / PV. The genotypic coefficient of variation (GCV), environmental coefficient of variation (ECV) and phenotypic coefficient of variation (PCV) were calculated using the formulas: $\mathrm{GCV}=(\sqrt{ } \mathrm{GV} / \mu) \mu) \times 100, \mathrm{ECV}=(\sqrt{ } \mathrm{EV} / \mu \mu$ )$\times 100, \mathrm{PCV}=(\sqrt{ } \mathrm{PV} / \mu \mu) \times 100$ where $\mu \mu$ is the mean value of the particular trait of interest. 
Table 01: List of the rapeseed F6 lines studied.

\begin{tabular}{cllcll}
\hline No. & Genotype code & \multicolumn{1}{c}{ Parents } & No. & \multicolumn{1}{c}{ Genotype code } & \multicolumn{1}{c}{ Parents } \\
\hline 1 & RW308 $(\mathrm{G} 1)$ & RW x L308 & 19 & RG3SAR(G19) & RG003 x Sarigol \\
2 & RWR401(G2) & RW x L401 & 20 & RWSAR(G20) & RW x Sarigol \\
3 & SAR308(G3) & Sarigol x L308 & 21 & RAS19(G21) & RAS x 19R \\
4 & RG3401(G4) & RG003 x L401 & 22 & 19RG3(G22) & 19R x RG003 \\
5 & RG6401(G5) & RG006 x L401 & 23 & RWRG3(G23) & RW x RG003 \\
6 & RG6308(G6) & RG006 x L308 & 24 & RASRW(G24) & RAS x RW \\
7 & 19R401(G7) & 19R x L308 & 25 & RASSAR(G25) & RAS x Sarigol \\
8 & 19R308(G8) & 19R x L308 & 26 & RASRG3(G26) & RAS x RG003 \\
9 & RG3308(G9) & RG003 x L308 & 27 & RASOPT(G27) & RAS x OPT \\
10 & AR401(G10) & AR x L401 & 28 & RASRG6(G28) & RAS x RG006 \\
11 & SAR308(G11) & Sarigol x L308 & 29 & ZAR401(G29) & Zarfam x L401 \\
12 & OPT308(G12) & OPT x L308 & 30 & RW19(G30) & RW x 19R \\
13 & OPT401(G13) & OPT x L401 & 31 & 19SAR-2(G31) & 19R x SAR2 \\
14 & RWRG3(G14) & RW x RG003 & 32 & 19SAR-3(G32) & 19R x SAR3 \\
15 & 19OPT(G15) & 19R x OPT & 33 & SARIGOL(G33) & Check1 \\
16 & RG3OPT(G16) & RG003 x OPT & 34 & RGS003(G34) & Check2 \\
17 & RWOPT(G17) & RW x OPT & 35 & Hyola401(G35) & Check3 \\
18 & 19SAR-1(G18) & 19R x Sarigol & 36 & Zarfam(G36) & Check4 \\
\hline
\end{tabular}

The correlation coefficients amoung the traits were estimated and then factor analysis on the base of major factors analysis and varimax rotations was done on the data. Principal components method analysis was used to extract factorial load of matrix and also to estimate the number of factors (Sharma. 1996). Therefore, the factors which had a root bigger than one were selected and were used to form factorial coefficients matrix. By means of varimax rotation, rotation was done on the major factorial loads matrix and the matrix of rotated factorial loads was obtained (Sharma. 1996; Rameeh, 2010). The average-linkage-between-groups method of cluster analysis, often aptly called UPGMA (un weighted pair-group method using arithmetic averages) was used, which defines the distance between two clusters as the average of the distances between all pairs of cases in which one member of the pair is from each of the clusters.. All the analyses were performed using MS-Excel and SAS software version 9 (SAS INSTITUTE INC, 2004).

\section{RESULTS AND DISCUSSIONS}

\section{Analysis of variance and genetic parameters of the traits}

Significant difference among mean square of genotypes were determined for the traits including days to flowering, days to maturity, plant height, pods per plant, seeds per pod, 1000-seed weight, seed and oil yields, indicating significant genetic variation for these traits (Table 02). This considerable variability provides a good opportunity for improving traits of interest in rapeseed breeding programs. Generally these results are similar to those reported by Aytac and Kinaci (2009), and Sabaghnia et al., (2010).

High phenotypic coefficients of variation (PCV) were recorded for plant height, number of pods per plant, seeds per pod, seed and oil yields. The high estimates of genetic coefficients of variation (GCV) were observed for pods per plant and seeds per pod, which indicates the presence of exploitable genetic variability for these traits (Table 03). Broad-sense heritability estimates 
$\left(h^{2} \mathrm{~B}\right)$ were greater for traits such as number of days to flowering, plant height and seeds per pod, hence, it is assumed that phenotypes for these traits are largely determined by their genotypes. Crop improvement for these traits is assumed to be possible by simple selection, due to high heritability coupled with high genotypic variation and additive gene effects (Aytaç et al., 2008).

\section{Mean values of the genotypes and correlation among the traits}

Mean values of most yield correlated traits and seed yield were high in the first year and it is due to suitable weather conditions at the first year (Table 04). Mean values of days to flowering ranged from 84.67 to 165.67 days in G5 and G36, respectively (Table 05). Significant positive correlation was detected between days to flowering and days to maturity (Table 06), suggested that selection for this trait should be done for early maturity genotypes. The genotypes including G1, G12, G18 and G35, with low means values of days to maturity are preferred for improving this trait. For reducing some of pests damages and also having enough opportunity for second crop cultivation after rapeseed, early maturity is ideotype trait for breeding Brassica napus L. and other related Brassica species. Plant height differed from 89.03 to $179.16 \mathrm{~cm}$ in G15 and G36, respectively. For ideotype breeding of rapeseed, low mean value of plant height is favored, therefore G4, G5, G6, G7, G11, G12, G15, G27 and G35 were merit genotypes for improving this trait. Since pods per plant and seeds per pod were significant positive correlated with seed yield, therefore G10, G18, G21, G25 and G32 with high mean values of pods per plant and also G23, G28, G29, G30, G31, G32 and G35 with high mean values of seeds per pod were considered as suitable genotypes for improving these traits. Zhang and Zhou (2006) reported that pods per plant, seeds per plant and 1000seed weight traits were positively correlated with seed yield. Jeromela et al. (2007) studied 30 rapeseed varieties and demonstrated that pods per plant have the highest correlation with seed yield. Khan et al. (2006) also reported the positive significant correlation between seed yield and plant height, pods per plant, seeds per pod and pod length. The genotypes, G2, G3, G6, G10, G31, G32 and G35 show high mean values of seed and oil yields.

Table 02: Summary of combined analysis of variance of traits measured on spring type repeseed genotypes.

\begin{tabular}{llllllllll}
\hline & & \multicolumn{7}{c}{ Mean square } \\
\cline { 3 - 10 } S.O.V & df & $\begin{array}{c}\text { Days to } \\
\text { flowering }\end{array}$ & $\begin{array}{c}\text { Days to } \\
\text { maturity }\end{array}$ & $\begin{array}{c}\text { Plant } \\
\text { height }\end{array}$ & $\begin{array}{c}\text { Pods per } \\
\text { plant }\end{array}$ & $\begin{array}{c}\text { Seeds } \\
\text { per pod }\end{array}$ & $\begin{array}{c}1000 \text {-seed } \\
\text { weight }\end{array}$ & $\begin{array}{c}\text { Seed } \\
\text { yield }\end{array}$ & $\begin{array}{c}\text { Oil } \\
\text { yield }\end{array}$ \\
\hline Year (Y) & 1 & $19059^{* *}$ & $6947^{* *}$ & $13305^{* *}$ & $28617^{* *}$ & 89 & 0.055 & $4090443^{*}$ & 497652 \\
Replication $/ \mathrm{Y}$ & 4 & 41 & 23 & 37 & 921 & 26 & 0.288 & 460066 & 136330 \\
Genotype(G) & 35 & $2041^{* *}$ & $98^{* *}$ & $2377^{* *}$ & $2992^{* *}$ & $105^{* *}$ & $1.272^{* *}$ & $922793^{* *}$ & $152260^{* *}$ \\
$\mathrm{Y} \times \mathrm{G}$ & 35 & $46^{* *}$ & $28^{* *}$ & 111 & 112 & 0.7 & 0.003 & 16890 & 7453 \\
Error & 140 & 6 & 7 & 281 & 198 & 5 & 0.196 & 89688 & 22716 \\
\hline
\end{tabular}

*, ** Significant at $\mathrm{p}=0.05$ and 0.01 , respectively. 
Table 03: Genetic parameters for different agronomic traits in 36 rapeseed genotypes.

\begin{tabular}{lrrrrrrr}
\hline \multicolumn{1}{c}{ Traits } & \multicolumn{1}{c}{$\mathrm{GV}^{1}$} & \multicolumn{1}{c}{$\mathrm{EV}^{2}$} & \multicolumn{1}{c}{$\mathrm{PV}^{3}$} & $\mathrm{GCV}^{4}$ & $\mathrm{PCV}^{5}$ & $\mathrm{ECV}^{6}$ & $\mathrm{~h}^{2} \mathrm{~B}^{7}$ \\
\hline Days to flowering & 332.5 & 6.1 & 338.6 & 14.45 & 14.59 & 1.96 & 0.98 \\
Days to maturity & 11.8 & 6.5 & 18.3 & 1.52 & 1.90 & 1.13 & 0.64 \\
Plant height & 377.6 & 280.6 & 658.2 & 13.01 & 17.18 & 11.21 & 0.57 \\
Pods per plant & 479.9 & 197.8 & 677.7 & 15.29 & 18.17 & 9.81 & 0.71 \\
Seeds per pod & 17.3 & 5.1 & 22.4 & 19.10 & 21.73 & 10.36 & 0.77 \\
1000-seed weight & 0.21 & 0.2 & 0.41 & 11.33 & 15.73 & 10.91 & 0.52 \\
Seed yield & 150983.8 & 89688.6 & 240672.4 & 13.46 & 16.99 & 10.37 & 0.63 \\
Oil yield & 24134.5 & 22716.8 & 46851.3 & 13.03 & 18.15 & 12.64 & 0.52 \\
\hline
\end{tabular}

$1,2, \ldots \ldots, 7$ are abbreviations for: Genotype Variance (GV), Error Variance (EV), Phenotype Variance (PV), Genotypic Coefficient of Variation (GCV), Phenotypic Coefficient of Variation (PCV), Environmental Coefficient of Variation (ECV) and Heritability (hi2), respectively.

Table 04: Means of studied traits of rapeseed genotypes over the two years of the experiment.

\begin{tabular}{rrrrrrrrr}
\hline Year & $\begin{array}{c}\text { Days to } \\
\text { flowering }\end{array}$ & $\begin{array}{c}\text { Days to } \\
\text { maturity }\end{array}$ & $\begin{array}{c}\text { Plant height } \\
(\mathrm{cm})\end{array}$ & $\begin{array}{c}\text { Pods per } \\
\text { plant }\end{array}$ & $\begin{array}{c}\text { Seeds } \\
\text { per pod }\end{array}$ & $\begin{array}{c}\text { 1000-seed } \\
\text { weight }(\mathrm{g})\end{array}$ & $\begin{array}{c}\text { Seed yield } \\
\left(\mathrm{kg} \mathrm{ha}^{-1}\right)\end{array}$ & $\begin{array}{c}\text { Oil } \\
\text { yield } \\
\left(\mathrm{kg} \mathrm{ha}^{-1}\right)\end{array}$ \\
\hline $2010-11$ & 116.76 & 219.76 & 157.22 & 154.83 & 22.43 & 4.08 & 3024.53 & 1240.41 \\
$2011-12$ & 135.55 & 231.10 & 141.52 & 131.81 & 21.15 & 4.04 & 2749.30 & 1144.41 \\
\hline
\end{tabular}

Table 05: Means of traits measured in spring type oilseed rape genotypes.

\begin{tabular}{lrrrrrrrr}
\hline \multicolumn{1}{c}{ Genotypes } & $\begin{array}{r}\text { Days to } \\
\text { flowering }\end{array}$ & $\begin{array}{r}\text { Days to } \\
\text { maturity }\end{array}$ & $\begin{array}{r}\text { Plant } \\
\text { height }(\mathrm{cm})\end{array}$ & $\begin{array}{r}\text { Pods per } \\
\text { plant }\end{array}$ & $\begin{array}{r}\text { Seeds } \\
\text { per pod }\end{array}$ & $\begin{array}{r}\text { 1000-seed } \\
\text { weight }(\mathrm{g})\end{array}$ & $\begin{array}{r}\text { Seed yield } \\
\left(\mathrm{kg} \mathrm{ha}^{-1}\right)\end{array}$ & $\begin{array}{r}\text { Oil yield } \\
\left(\mathrm{kg} \mathrm{ha}^{-1}\right)\end{array}$ \\
\hline 1-RW308(G1) & 114.83 & 218.67 & 130.53 & 151.69 & 18.00 & 3.88 & 2713.17 & 1094.99 \\
2-RWR401(G2) & 132.83 & 224.83 & 169.88 & 151.61 & 23.22 & 4.08 & 3205.56 & 1346.34 \\
3-SAR308(G3) & 112.50 & 220.50 & 147.65 & 151.17 & 24.55 & 3.68 & 3303.39 & 1322.08 \\
4-RG3401(G4) & 110.00 & 222.83 & 125.38 & 115.78 & 18.20 & 4.78 & 2292.28 & 920.19 \\
5-RG6401(G5) & 84.67 & 222.00 & 126.00 & 146.03 & 20.50 & 3.73 & 3018.00 & 1212.80 \\
6-RG6308(G6) & 115.83 & 225.83 & 138.28 & 157.65 & 22.45 & 4.53 & 3296.77 & 1391.06 \\
7-19R401(G7) & 133.17 & 221.17 & 136.49 & 125.28 & 24.38 & 3.89 & 3038.00 & 1207.42 \\
8-19R308(G8) & 131.00 & 221.67 & 169.53 & 119.12 & 20.52 & 3.75 & 2746.11 & 1136.93 \\
9-RG3308(G9) & 126.67 & 225.17 & 143.70 & 140.48 & 24.93 & 3.14 & 3235.67 & 1327.03 \\
10-AR401(G10) & 140.50 & 232.33 & 153.72 & 172.20 & 19.73 & 4.76 & 3298.98 & 1339.48 \\
11-SAR308(G11) & 118.00 & 222.33 & 135.13 & 115.72 & 17.53 & 3.03 & 2108.22 & 872.83 \\
12-OPT308(G12) & 114.50 & 220.50 & 129.10 & 119.15 & 20.57 & 3.90 & 2728.17 & 1111.41 \\
13-OPT401(G13) & 93.83 & 225.17 & 154.76 & 167.72 & 20.62 & 4.01 & 2799.61 & 1142.17 \\
14-RWRG3(G14) & 132.83 & 230.00 & 160.57 & 123.65 & 14.53 & 4.75 & 2677.59 & 1126.07 \\
15-19OPT(G15) & 108.33 & 221.00 & 89.03 & 124.93 & 22.63 & 4.31 & 2586.83 & 1085.73 \\
16-RG3OPT(G16) & 112.50 & 222.83 & 131.87 & 106.78 & 15.48 & 3.58 & 2520.95 & 1022.21 \\
17-RWOPT(G17) & 94.83 & 216.00 & 117.52 & 105.03 & 20.35 & 4.59 & 2270.22 & 962.99 \\
18-19SAR-1(G18) & 145.50 & 229.83 & 180.42 & 171.90 & 19.30 & 3.53 & 3071.44 & 1296.37 \\
19-RG3SAR(G19) & 109.17 & 227.50 & 163.38 & 141.30 & 17.42 & 4.43 & 2702.78 & 1148.00 \\
20-RWSAR(G20) & 145.17 & 224.50 & 144.69 & 107.35 & 17.55 & 4.16 & 1994.11 & 866.50 \\
\hline
\end{tabular}


Table 05: Means of traits measured in spring type oilseed rape genotypes (Cont.)

\begin{tabular}{lcccccccc}
\hline 21-RAS19(G21) & 112.33 & 225.50 & 161.99 & 177.85 & 22.90 & 3.79 & 2997.22 & 1264.37 \\
22-19RG3(G22) & 131.83 & 222.50 & 173.74 & 114.87 & 21.17 & 4.16 & 2650.50 & 1080.38 \\
23-RWRG3(G23) & 164.67 & 225.67 & 177.55 & 149.23 & 29.92 & 4.85 & 3090.56 & 1342.26 \\
24-RASRW(G24) & 126.17 & 228.67 & 152.00 & 127.83 & 17.12 & 3.14 & 2875.28 & 1166.44 \\
25-RASSAR(G25) & 140.33 & 228.00 & 143.61 & 171.83 & 23.84 & 4.09 & 3068.33 & 1277.23 \\
26-RASRG3(G26) & 135.33 & 228.83 & 151.34 & 142.08 & 19.72 & 4.31 & 2781.99 & 1164.23 \\
27-RASOPT(G27) & 129.00 & 228.00 & 130.01 & 120.25 & 13.87 & 4.43 & 2209.44 & 918.80 \\
28-RASRG6(G28) & 128.67 & 232.67 & 142.59 & 155.83 & 26.08 & 4.51 & 3287.28 & 1346.38 \\
29-ZAR401(G29) & 150.00 & 231.67 & 168.24 & 159.95 & 26.35 & 3.92 & 3139.12 & 1360.53 \\
30-RW19(G30) & 117.67 & 227.33 & 152.85 & 154.42 & 26.52 & 4.43 & 3024.56 & 1247.95 \\
31-19SAR-2(G31) & 152.00 & 227.00 & 166.38 & 162.37 & 29.38 & 4.06 & 3388.89 & 1349.95 \\
32-19SAR-3(G32) & 134.83 & 228.33 & 170.26 & 177.19 & 30.12 & 4.24 & 3471.67 & 1417.83 \\
33-SARIGOL(G33) & 142.17 & 227.33 & 165.83 & 160.05 & 23.47 & 3.59 & 2952.66 & 1183.95 \\
34-RGS003(G34) & 118.33 & 227.83 & 158.80 & 166.58 & 20.12 & 3.96 & 3148.53 & 1294.52 \\
35-Hyola401(G35) & 115.83 & 220.67 & 138.34 & 163.93 & 27.00 & 4.16 & 3578.06 & 1476.40 \\
36-Zarfam(G36) & 165.67 & 230.83 & 176.16 & 140.55 & 24.43 & 3.99 & 2657.01 & 1102.89 \\
\hline \multicolumn{1}{c}{ LSD $(a=0.01)$} & 3.63 & 3.93 & 24.87 & 20.88 & 3.32 & 0.66 & 444.36 & 223.63 \\
\hline
\end{tabular}

Table 06. Correlation among the traits in 36 rapeseed genotypes.

\begin{tabular}{lccccccc}
\hline \multicolumn{1}{c}{ Traits } & $\begin{array}{c}\text { Days to } \\
\text { flowering }\end{array}$ & $\begin{array}{c}\text { Days to } \\
\text { maturity }\end{array}$ & $\begin{array}{c}\text { Plant } \\
\text { height }\end{array}$ & $\begin{array}{c}\text { Pods per } \\
\text { plant }\end{array}$ & $\begin{array}{c}\text { Seeds } \\
\text { per pod }\end{array}$ & $\begin{array}{c}1000 \text {-seed } \\
\text { weight }\end{array}$ & $\begin{array}{c}\text { Seed } \\
\text { yield }\end{array}$ \\
\hline Days to maturity & $0.57^{* *}$ & & & & & & \\
Plant height & $0.63^{* *}$ & $0.54^{* *}$ & & & & & \\
Pods per plant & 0.17 & $0.47^{* *}$ & $0.43^{* *}$ & & & & \\
Seeds per pod & $0.34^{*}$ & 0.10 & 0.29 & $0.54^{* *}$ & & & \\
1000-seed weight & 0.07 & 0.16 & -0.05 & 0.03 & 0.08 & & \\
Seed yield & 0.18 & 0.31 & $0.37^{*}$ & $0.78^{* *}$ & $0.70^{* *}$ & -0.01 & \\
Oil yield & 0.23 & $0.34^{*}$ & $0.41^{*}$ & $0.79^{* *}$ & $0.71^{* *}$ & 0.05 & $0.95^{* * *}$ \\
\hline
\end{tabular}

$*, * *$ Significant at $\mathrm{p}=0.05$ and 0.01 , respectively.

\section{Multivariate analyses}

The results of stepwise regression analysis are shown in Table 07. Seed yield was considered a dependent variable, while other traits were considered independent variables. Number of pods per plant was entered in the model first and explained $62 \%$ of variation; then seeds per pod were entered into the model. Cluster analysis indicates the extent of genetic diversity that is of practical use in plant breeding (Mahasi and Kamundia 2007). Rapeseed genotypes used in this study were grouped in three clusters $(\mathrm{C} 1, \mathrm{C} 2$ and $\mathrm{C} 3$ ), comprised of 11, 9 and 16 genotypes, respectively (Figure 01). Means of various traits for each character showed that genotypes with minimum number of seeds per pod and pods per plant were grouped in cluster C3. Genotypes with maximum plant height, days to maturity, pods per plant, seeds per pod and seed and oil yields were grouped in cluster C2. Genotypes with minimum 100-seed weight were classified in cluster $\mathrm{C} 2$. The cluster analysis supported the results of correlation coefficients, and both 
indicated that plant height, number of pods per plant and seeds per pod may be simultaneously improved and accumulated in a single genotype for seed yield improvement in rapeseed (Table 08). This is supported by the fact that all these four components were positively associated with seed yield and with each other. Furthermore, rapeseed genotypes with high mean values for these traits as well as high seed yield were grouped in cluster $\mathrm{C} 2$. It can be concluded that seed yield in rapeseed can be improved by selecting for an ideotype having higher number of pods per plant, number of seeds per plant. Genetic diversity among the Brassica genotypes was assessed by Choudhary and Joshi (2001) using cluster analysis.

Table 07: The results of stepwise regression analysis of 8 studied traits of the rapeseed genotypes.

\begin{tabular}{ccccc}
\hline Step & Variable entered & Partial R-square & Model R-square & F-test \\
1 & $\mathrm{X}_{4}$ :pods per plant & 0.62 & 0.62 & $53.38^{* *}$ \\
2 & $\mathrm{X}_{5}$ :seeds per pod & 0.11 & 0.73 & $13.35^{* *}$ \\
\hline
\end{tabular}

Final regression model: $\mathrm{Y}($ seed yield $)=635.18+10.9 \mathrm{X} 4+36.94 \mathrm{X} 5$

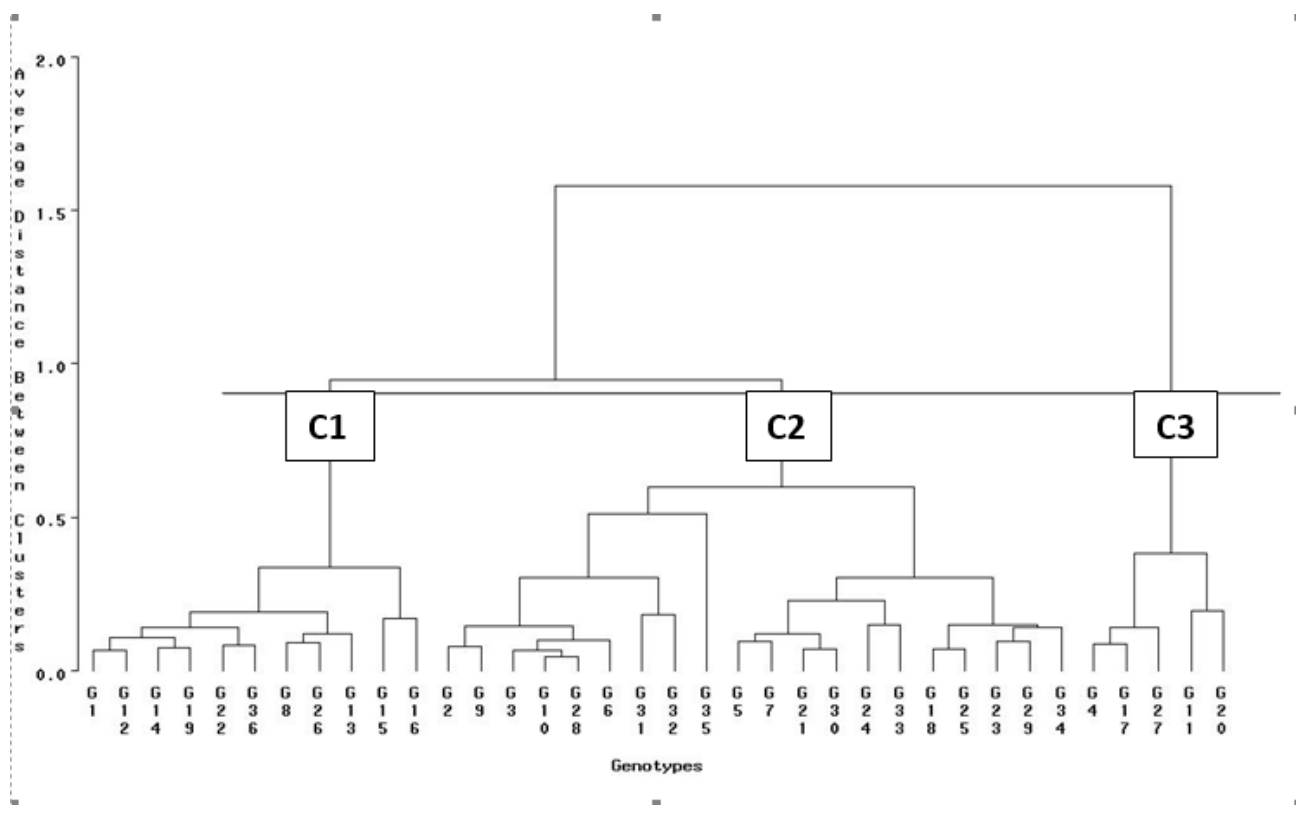

Figure 01: Clustering dendrogram of 36 rapeseed genotypes (the genotypes code as in Table 1) based on 8 studied traits.

Table 08: The means of clustering groups for eight studied traits of the rapeseed genotypes.

\begin{tabular}{ccccccccc}
\hline $\begin{array}{c}\text { Traits } \\
\begin{array}{c}\text { Clustering } \\
\text { groups }\end{array}\end{array}$ & $\begin{array}{c}\text { Days to } \\
\text { flowering }\end{array}$ & $\begin{array}{c}\text { Days to } \\
\text { maturity }\end{array}$ & $\begin{array}{c}\text { Plant } \\
\text { height }(\mathrm{cm})\end{array}$ & $\begin{array}{c}\text { Pods per } \\
\text { plant }\end{array}$ & $\begin{array}{c}\text { Seeds } \\
\text { per pod }\end{array}$ & $\begin{array}{c}\text { 1000-seed } \\
\text { weight }(\mathrm{g})\end{array}$ & $\begin{array}{c}\text { Seed yield } \\
\left(\mathrm{kg} \mathrm{ha}^{-1}\right)\end{array}$ & $\begin{array}{c}\text { Oil yield } \\
\left(\mathrm{kg} \mathrm{ha}^{-1}\right)\end{array}$ \\
\hline C1 & 124.4 & 224.1 & 147.5 & 130.5 & 19.9 & 4.1 & 2733.5 & 1126.8 \\
C2 & 129.7 & 226.6 & 154.7 & 157.2 & 24.1 & 4.0 & 3174.5 & 1308.5 \\
C3 & 119.4 & 222.7 & 130.5 & 112.8 & 17.5 & 4.2 & 2174.9 & 908.3 \\
\hline
\end{tabular}




\section{CONCLUSIONS}

In general days to flowering, pods per plant and seeds per pod were more heritable than the other traits. Due to significant positive correlation of yield components including seeds per pod and pods per plant with seed yield these traits can be used as indirect selection criteria for improving seed yield. The low value of genetic coefficient of variation for days to maturity suggests that for improving this trait, the correlated trait including days to flowering can be used. Cluster analysis can be used as suitable method for classifying the high yield genotypes. The results of cluster analysis supported the results of correlation coefficients, and both indicated that plant height, number of pods per plant and seeds per pod can be used as indirection selection criteria for improving of seed yield in rapeseed genotypes.

\section{ACKNOWLEDGEMENTS}

The author wish to thanks Agricultural and Natural Resources Research Center of Mazandaran and Seed and Plant Improvement Institute (SPII) for providing genetic materials and facility for conducting this experiment.

\section{REFERENCES}

Aytac, Z., Kinaci, G. and Kinaci, E. (2008). Genetic variation, heritability and path analysis of summer rapeseed cultivars, Journal of Applied Biological Sciences.2:35-39.

Aytac, Z. and Kinaci, G. (2009). Genetic variability and association studies of some quantitative characters in winter rapeseed (Brassica napus L.), African Journal of Biotechnology. 8: 3547-3554.

Basalma, D. (2008). The Correlation and Path Analysis of Yield and Yield Components of Different Winter Rapeseed (Brassica napus ssp. oleifera L.) Cultivars, Research Journal of Agriculture and Biological Sciences. 4: 120-125.

Choudhary, B.R. and Joshi, P. (2001). Genetic diversity in advanced derivatives of Brassica interspecific hybrids, Euphytica. 121: 1-7.

Friedt, W., Snowdon, R., Ordon, F. and Ahlemeyer, J. (2007). Plant Breeding: assessment of Genetic Diversity in Crop Plants and its Exploitation in Breeding, Progress in Botany. 168: 152-177.

Hashemi Ameneh, S., Nematzadeh, G.A., Babaeian Jelodar, N. and Ghasemi Chapi, O. (2010). Genetic evaluation of yield and yield components at advanced generations in rapeseed (Brassica napus L.), African Journal of Agricultural Research. 5(15): 1958-1964.

Ivanovska, S., Stojkovski, C., Dimov, Z., Marjanovic-Jeromela, A., Jankulovska, M. and Jankuloski, L.J. (2007). Interrelationship Between Yield and Yield Related Traits of Spring Canola (Brassica napus L.) Genotypes, Genetika. 39: 325-332.

Jeromela, A., Marinkovic, R., Mijic, A., Jankulovska, M. and Zdunic Z. (2007). Interrelationship between oil yield and other quantitative traits in rapeseed (Brassica napus L.), Journal of Central European Agriculture. 8: 165-170. 
Khachatourians, G.G., Summer, A.K. and Phillips, P.W.B. (2001). An Introduction to the History of Canola and the Scientific Basis for Innovation. CABI, London.

Khan, F.A., Ali, S., Shakeel, A., Saeed, A. and Abbas, G. (2006). Correlation analysis of some quantitative characters in Brassica napus L., Journal of Agricultural Research . 44, 7-14.

Khan, S., Farhatullah, I. and Khallil, H. (2008). Phenotypic correlation analysis of elite F3:4 Brassica populations for quantitative and qualitative traits, ARPN Journal of Agricultural and Biological Science . 3, 38-42.

Leilah, A.A. and Al-Khateeb, S.A. (2005). Yield analysis of canola (Brassica napus L.) using some statistical procedures. Saudi Journal of Biological Sciences 12: 103-113.

Madson, E. (1976). Nuclear magnetic resonance spectrometry: A method of determination of oil content in rapeseed oil, Journal of the American Oil Chemists' Society. 53:467-469.

Mahasi, M.J. and Kamundia, J.W. (2007). Cluster analysis in rapeseed (Brassica napus L.), African Journal of Agricultural Research. 2 : 409-411.

Marjanovic-Jeromela, A., Kondic-Spika, A., Saftic-Pankovic, D., Marinkovic, R. and Hristov, N. (2009). Phenotypic and molecular evaluation of genetic diversity of rapeseed (Brassica napusL.) genotypes, African Journal of Biotechnology. 8: 4835-4844.

Naderi, R. and Emam, Y. (2010). Interrelationships among grain yield and related characters of four oilseed rape (Brassica napus L.) cultivars under drought stress conditions, DESERT. 15: 133-138.

Rameeh, V. (2010). Combining ability and factor analysis in $\mathrm{F}_{2}$ diallel crosses of rapeseed varieties, Plant Breeding and Seed Science. 62: 73-83.

Sabaghnia, N., Dehghani, H., Alizadeh, B. and Mohghaddam, M. (2010). Interrelationships between seed yield and 20 related traits of 49 canola (Brassica napusL.) genotypes in non-stressed and water-stressed environments, Spanish Journal of Agricultural Research. 8: 356-370.

SAS INSTITUTE INC.2004. SAS/STAT user's guide. Version 9. Fourth Edition. Statistical Analysis Institute Inc., Cary North Carolina.

Semahegn Belete, Y. (2011). Genetic variability, correlation and path analysis studies in Ethiopian Mustard (Brassica carinata A. Brun) Genotypes. International Journal of Plant Breeding and Genetics 5: 328-338.

Sharma, S. (1996). Applied Multivariate Techniques. 1st ed. John Wiley and Sons, New York, pp: 493.

Sheikh, F.A, Rather, A.G. and Wani, S.A. (1999). Genetic variability and inter-relationship in toria (Brassica campestris L. var. Tori). Current Advances in Plant Science 12: 139-143.

Singh, M., Ceccarelli, S. and Hamblin, J. (1993). Estimation of heritability from varietal trials data, Theoretical and Applied Genetics. 86: 437-441. 
Zhang, G. and Zhou, W. (2006). Genetic analysis of agronomic and seed quality traits of synthetic oilseed Brassica napus produced from inter specific hybridization of B. campestris L. and $B$. oleracea L., Journal of Genetics. 85: 45-51. 